\title{
Angka Kejadian Bayi Berat Badan Lahir Rendah Sebelum dan Semasa Krisis Ekonomi; suatu Penelitian di Rumah Sakit
}

\author{
Sjarif Hidayat, Kiki Madiapermana K Samsi, Mia Milanti Dewi*
}

Krisis ekonomi yang terjadi sejak tahun 1997 memberikan dampak yang luas dan meresahkan masyarakat. Masyarakat menduga krisis ekonomi mengakibatkan gizi buruk pada bayi baru lahir dengan indikator bayi berat lahir rendah (BLBR). Ilmu Kesehatan Anak menggunakan kelahiran bayi kecil masa kehamilan (KMK) sebagai indikator gizi buruk pada bayi baru lahir. Kondisi lain yang mengakibatkan kelahiran BBLR adalah prematuritas. Penulis merasa perlu meneliti sejauh mana pengaruh krisis ekonomi terhadap kelahiran BBLR, baik dalam bentuk KMK ataupun prematuritas. Penelitian ini bersifat retrospektif. Subjek penelitian adalah semua BBLR lahir hidup di Rumah Sakit Hasan Sadikin Bandung sebelum krisis ekonomi antara Oktober sampai Desember 1998 (kelompok II). Data didapat dari rekam medik. Dari 83 bayi dalam kelompok I didapatkan bayi KMK sebanyak 50 bayi (60\%), 28 bayi (55\%) tipe simetris; bayi prematur 25 bayi (30\%); bayi prematur-KMK 6 bayi (22\%). Sedangkan dari 86 bayi dalam kelompok II didapatkan bayi KMK sebanyak 34 bayi (39,5\%), 19 (56\%) tipe simetris; bayi prematur 45 bayi (52\%); bayi prematur-KMK 7 (16\%). Berdasarkan uji X_ didapatkan penurunan bermakna dari jumlah bayi KMK pada BBLR semasa krisis ekonomi $(p=0,007)$. Namun di lain pihak terdapat peningkatan bermakna dari jumlah bayi prematur pada BBLR semasa krisis ekonomi ( $p=0,007)$. Sedangkan jumlah bayi prematur-KMK pada bayi BBLR sebelum dibandingkan dengan semasa krisis ekonomi tidak didapatkan perbedaan ( $\mathrm{p}=0.384$ ). Dapat disimpulkan bahwa jumlah kelahiran bayi KMK justru mengalami penurunan semasa krisis ekonomi. Sedangkan krisis ekonomi ternyata lebih berdampak pada peningkatan kelahiran bayi prematur yang juga merupakan permasalahan di bidang kesehatan anak.

Kata Kunci: BBLR (berat badan lahir rendah), KMK (kecil masa kehamilan), prematur

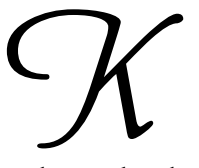

risis ekonomi yang melanda Indonesia sejak pertengahan tahun 1997 telah memberi dampak yang luas di berbagai sektor baik sektor industri, pertanian dan sosialekonomi, termasuk dampak pada dunia kesehatan. ${ }^{1}$ Pemberitaan di berbagai media massa mengenai adanya kecenderungan peningkatan bayi bergizi buruk,

Alamat korespondensi: Dr. Sjarif Hidayat, Sp.A.

Bagian Ilmu Kesehatan Anak FK-UNPAD/ Rumah Sakit Dr. Hasan Sadikin Bandung. Jl. Pasteur no.38, Bandung.

Telepon: 022-2034426 Fax: 022-2035957. khususnya di Sumatera Barat, cukup meresahkan dunia kesehatan. Selain itu masyarakat menduga krisis ekonomi mengakibatkan gizi buruk pada bayi baru lahir, sedangkan indikator di bidang Ilmu Kesehatan Anak adalah bayi kecil masa kehamilan (KMK). ${ }^{2-6}$

Selain KMK kondisi lain yang berperan dalam kelahiran BBLR prematuritas. Apapun jenisnya (KMK atau prematuritas), kelahiran bayi BBLR akan meningkatkan morbiditas dan mortalitas bayi, serta menyebabkan penurunan kualitas sumber daya optimal generasi mendatang. ${ }^{2-11}$ Bayi berat lahir rendah baik dalam bentuk KMK atau prematuritas sangat dipengaruhi oleh kondisi ibu hamil seperti status gizi, 
anemia, kelelahan dan infeksi. ${ }^{4-9}$ Secara logika adanya krisis ekonomi (seperti perubahan status sosialekonomi, kelelahan ibu akibat harus bekerja) dapat mempengaruhi kondisi ibu hamil. Namun sejauh mana keadaan ini mempengaruhi kelahiran BBLR (KMK atau prematuritas) masih memerlukan penelitian lebih lanjut. Dari latar belakang kondisional, situasional serta tuntutan dan tantangan seperti yang telah diuraikan di atas, maka krisis ekonomi dan kejadian BBLR menjadi tema sentral masalah pada penelitian ini, yang dapat dirumuskan sebagai berikut :

Bayi yang sehat menjadi idaman setiap keluarga, terhindar dari morbiditas, mortalitas, dan gejala sisa dikemudian hari. Kelahiran bayi BBLR dapat mengganggu pencapaian harapan tersebut. Gangguan status sosial ekonomi merupakan salah satu faktor predisposisi BBLR. Krisis ekonomi secara langsung berdampak terhadap semua sistem kemasyarakatan di Indonesia. Data mengenai hubungan antara krisis ekonomi dengan kelahiran bayi BBLR perlu dikaji.

Ketidaklengkapan informasi tentang hubungan krisis ekonomi dengan kejadian BBLR menggugah kami melakukan penelitian untuk mendapat gambaran sejauh mana krisis ekonomi mempengaruhi kelahiran BBLR baik dalam bentuk KMK ataupun prematuritas .

\section{Subyek dan Metode Penelitian}

Penelitian ini bersifat retrospektif - cross sectional. Subjek penelitian adalah semua bayi lahir hidup dengan berat lahir rendah (BBLR) di RSHS-Bandung sebelum krisis ekonomi yaitu periode Oktober sampai Desember 1996 (kelompok I) dan semasa krisis ekonomi yaitu periode Oktober sampai dengan Desember 1998 (kelompok II). Data diambil dari rekam medik RS Hasan Sadikin Bandung. Usia kehamilan ditentukan berdasarkan nilai Dubowitz, simplified Dubowitz, atau Ballard. Sedangkan penentuan bayi kecil/sesuai/besar masa kehamilan ditentukan berdasarkan kurva Lubchenco. ${ }^{3}$ Analisa statistik dilakukan dengan komputer dan piranti lunak SPSS 9.0 for Window. Tingkat kemaknaan yang diharapkan $\mathrm{p}<0,001$.

\section{Hasil Penelitian}

Jumlah kelahiran pada bulan Oktober-Desember 1996 sebanyak 678 bayi, 105 bayi lahir dengan berat badan kurang dari $2500 \mathrm{~g}$ (BBLR). Sedangkan jumlah kelahiran pada bulan Oktober-Desember 1998 sebanyak 576 bayi, 104 bayi lahir dengan berat badan kurang dari $2500 \mathrm{~g}$ (BBLR). Penelitian dilakukan terhadap 169 bayi BBLR yang lahir hidup dengan karakteristik seperti yang tertulis dalam Tabel 1 .

Pada karakteristik subyek penelitian, tidak terdapat perbedaan bermakna dari jumlah subyek penelitian, rerata usia ibu, rerata usia ayah, jumlah ibu bekerja, jenis kelamin subjek, dan jumlah ibu anemia, baik sebelum ataupun selama krisis ekonomi (Tabel 2).

Pada kelompok I terdapat 83 subyek penelitian sedangkan pada kelompok II terdapat 86 subyek penelitian. Perbandingan jumlah kelahiran bayi KMK pada bayi BBLR sebelum dan semasa krisis ekonomi memberi hasil sebagai berikut (Tabel 3).

Terdapat penurunan bermakna dari jumlah kelahiran bayi KMK sebelum dan semasa krisis ekonomi. Pada kedua kelompok tidak terdapat perbedaan karakteristik tipe bayi KMK, seperti tercantum dalam Tabel 4.

Tabel 1. Karakteristik subyek penelitian

\begin{tabular}{lccc}
\hline Karakteristik & Sebelum krisis ekonomi & Selama krisis ekonomi & $\rho$ \\
\hline Subyek penelitian & 83 & 86 & 0,503 \\
Rerata usia ibu (tahun) & 26,47 & 27,51 & 0,366 \\
Rerata usia ayah (tahun) & 29,34 & 32,51 & 0,065 \\
Jumlah ibu bekerja & 14 & 26 & 0,550 \\
Jenis kelamin perempuan & 41 & 43 & 0,938 \\
Jenis kelamin laki-laki & 42 & 43 & 0,938 \\
Ibu anemia & 17 & 12 & 0,260
\end{tabular}

$\rho=$ tingkat kemaknaan 
Tabel 2. Perbandingan jumlah kelahiran bayi KMK pada bayi BBLR

\begin{tabular}{lcc}
\hline Jumlah Kelahiran Bayi & SMK & KMK \\
\hline $\begin{array}{l}\text { Sebelum krisis ekonomi } \\
\quad \text { (kelompok I) }\end{array}$ & 33 & 50 \\
$\begin{array}{l}\text { Semasa krisis (kelompok II) } \\
\text { Jumlah }\end{array}$ & 52 & 34 \\
\hline $\begin{array}{l}\rho=0,007 \\
\text { SMK = sesuai masa kehamilan } \\
\text { KMK = kecil masa kehamilan }\end{array}$ & 85 & 84 \\
\hline
\end{tabular}

Tabel 4. Perbandingan jumlah kelahiran bayi prematur pada bayi BBLR

\begin{tabular}{lccc}
\hline Jumlah Kelahiran Bayi & Prematur & Matur & Postmatur \\
\hline $\begin{array}{c}\text { Sebelum krisis ekonomi } \\
\text { (kelompok 1) }\end{array}$ & 25 & 56 & 2 \\
$\begin{array}{c}\text { Semasa krisis ekonomi } \\
\text { (kelompok II) }\end{array}$ & 45 & 41 & 0 \\
\hline Jumlah & 70 & 97 & 2 \\
\hline
\end{tabular}

$\rho=0,007$

Perbandingan jumlah kelahiran bayi prematur sebelum dan semasa krisis ekonomi memberi hasil sebagai berikut:

- Terdapat peningkatan bermakna dari jumlah kelahiran bayi prematur sebelum dan semasa krisis ekonomi.

- Perbandingan jumlah kelahiran bayi KMK pada kelahiran prematur sebelum dan semasa krisis ekonomi memberi hasil sebagai berikut.

- Tidak terdapat perbedaan bermakna dari kelahiran bayi prematur-KMK sebelum dan semasa krisis ekonomi.

\section{Diskusi}

Penelitian ini dilakukan dengan mengambil data BBLR lahir hidup di RSHS pada bulan Oktober-Desember 1998. Populasi penelitian ini adalah bayi BBLR. Masyarakat pada umumnya, baik masyarakat awam ataupun di bidang kesehatan lebih mengenal kelahiran BBLR sebagai bentuk akibat adanya gangguan pertumbuhan intra uterin. ${ }^{1}$ Sedangkan BBLR sendiri terdiri dari berbagai macam bentuk dengan etiologi yang berbeda. Bidang Ilmu Kesehatan Anak saat ini menggunakan kelahiran bayi KMK sebagai indikator
Tabel 3. Tipe KMK sebelum dan selama krisis ekonomi.

\begin{tabular}{lcc}
\hline Jumlah Kelahiran Bayi & Simetris & Asimetris \\
\hline $\begin{array}{c}\text { Sebelum krisis ekonomi } \\
\text { (kelompok 1) }\end{array}$ & 28 & 33 \\
$\begin{array}{c}\text { Semasa krisis ekonomi } \\
\text { (kelompok II) }\end{array}$ & $\begin{array}{c}(54,9 \%) \\
(45,1 \%)\end{array}$ & 15 \\
\hline Jumlah & $(55,9 \%)$ & $(44,1 \%)$ \\
\hline$\rho=0,27$ & 47 & 48 \\
\hline
\end{tabular}

Tabel 5. Perbandingan bayi prematur dengan KMK pada BBLR

\begin{tabular}{lll}
\hline Jumlah Kelahiran Bayi & SMK & KMK \\
\hline $\begin{array}{c}\text { Sebelum krisis ekonomi } \\
\quad \text { (kelompok I) }\end{array}$ & 19 & 6 \\
$\begin{array}{c}\text { Semasa krisis ekonomi } \\
\text { (kelompok II) }\end{array}$ & 38 & 7 \\
\hline Jumlah & 57 & 13 \\
\hline
\end{tabular}

$\rho=0,384$

adanya gizi buruk pada bayi baru lahir sebagai akibat dari pertumbuhan janin terhambat. Keadaan yang dapat menimbulkan BBLR adalah bayi matur sesuai masa kehamilan ( matur-SMK), bayi matur-KMK, bayi prematur SMK, bayi prematur KMK, bayi prematur besar masa kehamilan (BMK), dan bayi post maturSMK. ${ }^{2,3,4,9,10}$ Dalam penelitian ini observasi dilakukan terhadap kemungkinan adanya pengaruh krisis ekonomi terhadap gambaran kelahiran BBLR, khususnya KMK atau prematur. Subjek yang dipilih adalah bayi lahir hidup, karena unutk menentukan usia gestasi dengan menggunakan nilai Dubowitz, simplified Dubowitz dan Ballard, tidak dapat dilakukan pada bayi lahir mati. ${ }^{3}$

Pada observasi terhadap karakteristik subjek tidak terdapat perbedaan bermakna baik dari jumlah kelahiran BBLR, jumlah subyek penelitian, rerata usia ibu, rerata usia ayah, jumlah ibu bekerja, jenis kelamin subjek, dan jumlah ibu anemia. Kelemahan dalam penelitian ini adalah tidak terdapatnya data yang lengkap dan terperinci peyesuaian karakteristik penelitian yang merupakan faktor risiko terjadinya kelahiran bayi BBLR, baik akibat prematuritas ataupun akibat bayi KMK, seperti kenaikan berat badan ibu selama hamil, penyakit pada ibu saat hamil (hipertensi, infeksi, pendarahan, gangguan sistem pernafasan, gagal jantung), kebiasaan buruk ibu (merokok, penyalah- 
gunaan obat), jenis pekerjaan ibu, lama waktu pekerjaan ibu per hari/minggu/bulan. Sehingga diperlukan suatu pendataan yang lengkap dan penelitian prospektif untuk mengamati adanya perubahan karakteristik populasi sebelum dan selama krisis ekonomi. ${ }^{2,4,10,11}$

Jumlah kelahiran BBLR sebelum dan selama krisis ekonomi tidak menunjukkan perbedaan bermakna. Bila tidak dianalisa lebih mendalam maka terkesan bahwa tidak ada dampak krisis ekonomi terhadap kualitas bayi baru lahir. Terlebih bila ditambah dengan hasil analisa terhadap kelahiran KMK yang justru secara bermakna mengalami penurunan semasa krisis ekonomi. Kedua hal ini dapat mengurangi kewaspadaan kita akan dampak krisis ekonomi. Pada analisa selanjutnya ternyata terdapat peningkatan bermakna dari kelahiran bayi prematur semasa krisis ekonomi. Peningkatan kelahiran bayi prematur ini akan menimbulkan peningkatan morbiditas dan mortalitas yang pada akhirnya akan menurunkan kualitas generasi mendatang. Morbiditas dan mortalitas dapat diperburuk lagi bila jumlah bayi prematur-KMK meningkat. ${ }^{12}$ Namun demikian pada penelitian ini tidak terdapat perbedaan bermakna dari jumlah kelahiran bayi prematur-KMK.

Beberapa hal yang masih menjadi pertanyaan dan perlu dilakukan penelitian lebih lanjut adalah faktor penyebab penurunan kelahiran bayi KMK selama krisis ekonomi, faktor risiko yang menyebabkan peningkatan kelahiran bayi prematur, apakah penurunan kelahiran bayi KMK berhubungan dengan peningkatan kelahiran bayi prematur, mungkinkah bayi yang lahir prematur dalam penelitian ini bila dapat dipertahankan kehamilannya sampai matur akan menghasilkan bayi matur-KMK, bagaimana morbiditas dan mortalitas bayi pada penelitian ini dalam beberapa tahun mendatang.

\section{Kesimpulan}

Krisis ekonomi tidak berdampak terhadap peningkatan kelahiran bagi KMK, namun berdampak terhadap peningkatan kelahiran prematur. Hal ini memerlukan kewaspadaan dan penatalaksanaan optimal yang melibatkan orang tua, masyarakat umum, pemerintah, serta petugas kesehatan terutama yang terkait di bidang perinatologi. Penelitian lanjutan diperlukan untuk identifikasi permasalahan yang dapat menimbulkan peningkatan kelahiran prematur dalam upaya mencegah peningkatan kelahiran bayi prematur mengingat krisis ekonomi masih terus berlangsung.

\section{Daftar Pustaka}

1. Hadi U, Soemitro S. Permasalahan serta implikasi kebijakan dalam bidang ekonomi kesehatan di propinsi Jawa Barat. Disampaikan pada Semiloka Kajian Masalah Kesehatan di Jawa Barat, 19 Juni 1999.

2. Adeniyi SC. Intrauterine growth retardatio. Dalam : Spitzer AR, penyunting Intensive care of the fetus and neonate. St. Louis : Mosby-Year Book, 1996. h. 137-48.

3. Lubchenco LO, Hansman C, Dresser M, Boyd E. Intrauterine growth as estimated from live born birth weight data at 42 week of gestation. Pediatrics 1963; 32:793-800.

4. Pursley DM, Cloherty JP, Identifying the highrisk newborn age evaluating gestational age, prematurity, posmaturity, large-for-gestational-age, small-forgestational-age infants. Dalam Cloherty JP, Stark AR, penyunting. Manual of neonatal care, edisi ke 4 . Philadelphia: Lippincot-Raven, 1998. h. 37-51

5. Sohl B, Moore TR. Abnormalities of fetal growth: intrauterine growth restriction. Dalam : Taeusch HW, Ballard RA, penyunting. Avery's disease of the newborn, edisi ke-7. Philadelphia : WB Saunders CO,1998. h. 90101.

6. Creasy RK, Resnick R. Intrauterine growth restriction. Dalam: Creasy RK, Resnick, penyunting. Maternal-fetal medicine : principles and practice. Philadelphia:WB Saunders, 1994. h. 558-74.

7. Warshaw JB. Intrauterine growth retardation. Pediatr Rev, 1986; 8:107-14

8. Chamberlain G. Small for gestational age. Br Med J, 1991; 302: 1592-6.

9. Crouse DT, Cassady G. The Small-for-gestational age infant. Dalam: Avery GB, Flecther MA, Mac Donald MG, penyunting. Neonatology: Pathofisiology and management of the newborn. JB Lippincott, Philadelphia, 1994. h. 12531

10. Vik T, Vatten L, Markestad T, Ahisten G, Jackobsen G, Bakketeig LS. Morbidity during the first year of life in small for gestational age infant. Arch Dis Child, 1996; 75:133-7.

11. Jhonston PGB. Vulliamy"s the newborn child, edisi ke7. Edinburg: Churchill Livingstone, 1994. h. 69-82.

12. Barros FC, Hutty SRA, Victoria CG, Kirikwood BR, Vaughan JP. Comparison of the causes and consequenses of prematurity and IUGR: a longitudinal study in Southern Brazil. Pediatrics, 1992; 90:233-44. 